The Reluctant Communist 
The publisher gratefully acknowledges the generous contribution to this book provided by the Asian Studies Endowment Fund of the University of California Press Foundation. 


\section{The Reluctant Communist}

My Desertion, Court-Martial, and

Forty-Year Imprisonment in North Korea

Charles Robert Jenkins

with Jim Frederick

\section{甲}

UNIVERSITY OF CALIFORNIA PRESS

Berkeley Los Angeles London 
University of California Press, one of the most distinguished university presses in the United States, enriches lives around the world by advancing scholarship in the humanities, social sciences, and natural sciences. Its activities are supported by the UC Press Foundation and by philanthropic contributions from individuals and institutions. For more information, visit www.ucpress.edu.

University of California Press

Berkeley and Los Angeles, California

University of California Press, Ltd.

London, England

(C) 2008 by The Regents of the University of California

Foreword $\odot 2008$ by Jim Frederick

Library of Congress Cataloging-in-Publication Data

Jenkins, Charles Robert, I940-

The reluctant communist: my desertion, court-martial, and forty-year imprisonment in North Korea.

p. cm.

"Japanese edition, To Tell the Truth (Kokuhaku, or Confession), was published by Kadokawa Shoten”-ECIP Dataview. ISBN 978-0-520-25333-9 (cloth : alk. paper)

I. Jenkins, Charles Robert, I940- 2. Korean War, I950-I953Personal narratives, American. 3. Korean War, 1950-1953Desertions_-United States. 4. Military deserters-United States-Biography. 5. Americans-Korea (North)-Biography. 6. Defectors-Korea (North)_Biography. 7. Korea (North)_Social life and customs. I. Frederick, Jim, I97I- II. Title

$$
\begin{aligned}
& \text { Ds92 I.6.J44 } 2008 \\
& \text { 355.I'334- dc22 }
\end{aligned}
$$

Manufactured in the United States of America

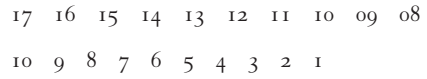

This book is printed on Natures Book, which contains $50 \%$ postconsumer waste and meets the minimum requirements of ANSI/NIso Z39.48-I992 (R I997) (Permanence of Paper). 
For my mother 
